\title{
Complement-independent bystander injury in AQP4-IgG seropositive neuromyelitis optica produced by antibody-dependent cellular cytotoxicity
}

\author{
Tianjiao Duan ${ }^{1,2}$, Alex J. Smith ${ }^{1}$ and Alan S. Verkman ${ }^{1 *}$
}

\begin{abstract}
Cellular injury in AQP4-lgG seropositive neuromyelitis spectrum disorder (herein called NMO) involves AQP4-IgG binding to astrocytes, resulting in astrocyte injury by complement-dependent cytotoxicity (CDC) and antibodydependent cellular cytotoxicity (ADCC) mechanisms. The rapid disease progression, severe tissue damage, and abundant leukocyte infiltration seen in some NMO patients suggest a more direct mechanism for demyelination and neurologic deficit than secondary injury from astrocyte loss. Here, we report evidence for an 'ADCC bystander mechanism' in NMO involving injury to nearby cells by leukocytes following their activation by AQP4-bound AQP4IgG on astrocytes. In model cocultures containing AQP4-expressing and null CHO cells, AQP4-lgG and complement killed bystander null cells to $100 \mu \mathrm{m}$ away from AQP4-expressing cells; AQP4-lgG and NK cells produced bystander killing to $\sim 300 \mu \mathrm{m}$, with perforin deposition seen on injured null cells. Bystander cytotoxicity was also seen with neutrophil-mediated ADCC and in astrocyte-neuron cocultures. Mechanistic studies, including real-time imaging, suggested that leukocytes activated by an AQP4-dependent ADCC mechanism injure bystander cells by direct targeted exocytosis on neighboring cells and not by diffusion of soluble granule contents. In support of this conclusion, ADCC bystander injury was preferentially reduced by an RGDS peptide that inhibits integrin adhesion. Evidence for ADCC bystander injury to oligodendrocytes and neurons was also found in mice following intracerebral injection of AQP4-lgG and NK cells, which was inhibited by RGDS peptide. These results establish a novel cellular pathogenesis mechanism in AQP4-lgG seropositive NMO and provide evidence that inflammatory mechanisms can cause widespread tissue damage in NMO independently of the secondary effects from astrocyte loss.
\end{abstract}

Keywords: NMO, Aquaporin-4, ADCC, Leukocyte, Astrocyte

\section{Introduction}

Neuromyelitis optica spectrum disorder (NMOSD) is an inflammatory demyelinating disease of the central nervous system distinct from multiple sclerosis. Most NMOSD patients are seropositive for IgG1 autoantibodies against aquaporin-4 (AQP4) [31, 32], a plasma membrane water channel expressed on astrocytes but not on other cell types in the central nervous system $[21,39,42]$. An initiating event in seropositive NMOSD (herein called NMO) is

\footnotetext{
* Correspondence: Alan.Verkman@ucsf.edu

'Departments of Medicine and Physiology, University of California, 1246

Health Sciences East Tower, 513 Parnassus Ave, San Francisco, CA

94143-0521, USA

Full list of author information is available at the end of the article
}

binding of anti-AQP4 autoantibodies (called AQP4-IgG) to AQP4 on astrocytes [27], which causes direct astrocyte injury by complement-dependent cytotoxicity (CDC) [23, $49,54]$ and antibody-dependent cellular cytotoxicity (ADCC) $[10,45,47,63]$ mechanisms. Injury to surrounding non-AQP4-expressing 'bystander' cells, such as oligodendrocytes, neurons and endothelial cells, leads to demyelination, neuron loss and consequent neurological deficit, which can include visual and motor deficits. It has been suggested that tissue damage in NMO is a secondary consequence of astrocyte loss [24, 27, 41], though inflammatory mechanisms may directly damage surrounding tissue in antibody-mediated autoimmunity [45].

(c) The Author(s). 2019 Open Access This article is distributed under the terms of the Creative Commons Attribution 4.0 International License (http://creativecommons.org/licenses/by/4.0/), which permits unrestricted use, distribution, and reproduction in any medium, provided you give appropriate credit to the original author(s) and the source, provide a link to the Creative Commons license, and indicate if changes were made. The Creative Commons Public Domain Dedication waiver (http://creativecommons.org/publicdomain/zero/1.0/) applies to the data made available in this article, unless otherwise stated. 
Injury to astrocytes by a CDC mechanism involves AQP4-IgG binding to AQP4 followed by binding of complement protein $\mathrm{C} 1 \mathrm{q}$ and activation of the classical complement pathway, resulting in the generation of anaphylatoxins and membrane attack complex (MAC) [4, $41,52]$. We recently reported a 'complement bystander injury' mechanism in NMO in which bystander cells near astrocytes, including oligodendrocytes, neurons and perhaps other cells, are injured following complement activation on astrocytes by local diffusion of short-lived, activated complement components leading to MAC formation on bystander cells $[19,60]$. We proposed that complement bystander injury may contribute to the early and marked demyelination and neuronal injury seen in human NMO and experimental animal models of NMO.

Astrocyte injury by an ADCC mechanism in NMO involves AQP4-IgG binding to astrocytes followed by binding and activation of various leukocytes, such as granulocytes, macrophages or NK cells, via Fcy receptors $[4,34,47,68]$. ADCC-mediated astrocyte injury can occur by a variety of mechanisms, including release of toxic granule contents such as perforin and proteases [53, 67]. Evidence for ADCC in NMO pathogenesis comes from human pathology showing prominent leukocyte infiltration and activation [33, 37, 49], in vitro cell models [10, $63]$, and experimental animal models $[47,68]$.

Leukocyte infiltration is associated with severe, necrotic NMO lesions [38]. Here, we postulated that an analogous 'ADCC bystander injury' mechanism could damage non-AQP4-expressing cells near astrocytes following Fcy receptor-mediated leukocyte activation. We report evidence, using coculture systems and mice, that activation of NK cells or neutrophils by AQP4-IgGcoated AQP4 expressing cells can lead to acute lysis of non-AQP4 expressing neighboring cells, supporting ADCC bystander injury as a mechanism of tissue damage in NMO.

\section{Materials and methods Materials}

Purified human monoclonal recombinant AQP4-IgG (rAb-53) [10, 16] was provided by Dr. Jeffrey Bennett (University of Colorado, Aurora, CO). Sera from confirmed seropositive NMO patients was provided by the Circles Bloodbank of the Guthy-Jackson Charitable Foundation. Human complement was purchased from Innovative Research (Novi, MI) and human (control) IgG from Thermo Fisher Scientific (Rockford, IL). Sprague-Dawley rats were purchased from Charles River Laboratories (Wilmington, MA) and bred at UCSF. All animal procedures were approved by the University of California, San Francisco Animal Care and Use Committee (IACUC).

\section{Cell culture}

Chinese hamster ovary $(\mathrm{CHO})$ cells stably expressing human AQP4-M23 (named CHO-AQP4 cells), as described $[16,44]$, were cultured at $37^{\circ} \mathrm{C}$ in $5 \% \mathrm{CO}_{2} 95 \%$ air in F-12 Ham's Nutrient Mixture medium supplemented with $10 \%$ fetal bovine serum, $200 \mu \mathrm{g} / \mathrm{ml}$ geneticin, $100 \mathrm{U} / \mathrm{ml}$ penicillin and $100 \mu \mathrm{g} / \mathrm{ml}$ streptomycin. Non-transfected $\mathrm{CHO}-\mathrm{K} 1$ cells without AQP4 (called $\mathrm{CHO}$-null cells) were cultured in the same medium but without geneticin. Human natural killer cells (NK cells) transfected to express the high-affinity $176 \mathrm{~V}$ variant of the Fcy receptor IIIA [66] were obtained from Fox Chase Cancer Center (Philadelphia, PA). NK cells were cultured in suspension in $\alpha$-MEM (Sigma-Aldrich, St. Louis, MO) containing $0.1 \mathrm{mM}$ 2-mercaptoethanol, 2 mM L-glutamine, $0.2 \mathrm{mM}$ myoinositol, 10\% FBS, $10 \%$ horse serum, $2.5 \mu \mathrm{M}$ folic acid, $5 \mathrm{ml}$ non-essential amino acids, $1 \mathrm{mM} \mathrm{Na}$ pyruvate, $1 \%$ penicillin/streptomycin, and $100 \mathrm{IU} / \mathrm{ml}$ of human recombinant interleukin-2 (GenScript, Piscataway, NJ). Primary astrocyte-neuron cocultures were generated from brains of embryonic day 18 Sprague-Dawley rats (neurons) or cerebral cortex of neonatal rats (astrocytes) as described [19].

Neutrophils were isolated from human peripheral blood by a modified Ficoll-Hypaque method [20, 40] using density gradient centrifugation and a commercial separation medium (Lympholyte-poly, CL5071, Cedarlane Labs, Burlington, NC) containing sodium metrizoate and dextran 500. After separation, red cell lysis buffer was added to the neutrophil layer to lyse residual red cells. The isolated neutrophils were resuspended in HBSS/HSA solution (2\% HSA) at specified concentration and used within $2 \mathrm{~h}$. Neutrophil purity was $97.0 \%$ as judged by immunofluorescence using neutrophil-specific CD66b antibody (1:200, 555723, BD Pharmingen, San Jose, CA).

\section{Complement-dependent cytotoxicity}

$\mathrm{CHO}-\mathrm{AQP} 4$ and $\mathrm{CHO}-$ null cells were cultured individually or at specified cell number ratios (from 1:5 to 1:50) on coverslips in 24-well plates, and grown for 18-24 h until confluent. For assay of $\mathrm{CDC}, \mathrm{CHO}$ cells were incubated for $2 \mathrm{~h}$ at $37^{\circ} \mathrm{C}$ with $5 \%$ human complement and $10 \mu \mathrm{g} / \mathrm{ml}$ AQP4-IgG (or control human IgG) in Hank's balanced salt solution (HBSS, pH 7.2; Invitrogen, Camarillo, CA).

\section{Antibody-dependent cellular cytotoxicity}

For assay of ADCC, CHO-AQP4 and CHO-null cell cocultures were generated as for $\mathrm{CDC}$ experiments. Primary neurons were grown on coverslips in 12-well plates and astrocytes were added to neurons at a 1:20 ratio before experiments. NK-92 cells overexpressing CD16 were used as the effector cells. Cells were pre- 
incubated with $5 \mu \mathrm{g} / \mathrm{ml}$ AQP4-IgG (or control IgG) for $30 \mathrm{~min}$ at $37^{\circ} \mathrm{C}$. In some experiments, cells preincubated with a 1:100 dilution of serum of an AQP4-IgG seropositive NMO patient. NK cells or neutrophils were then added to the AQP4-IgG-coated CHO cells at an effector: target cell ratio of 5:1, and incubated for an additional 1 $\mathrm{h}$ at $37^{\circ} \mathrm{C}$. Following treatments, cells were washed extensively with Hank's Balanced Salt Solution (HBSS) to remove the remaining effector cells. In some studies, NK cells were pretreated with an inhibitor of the perforin cytotoxic pathway, concanamycin A (CMA, $10 \mathrm{nM}$, C9705, Sigma-Aldrich) [66] for $2 \mathrm{~h}$ prior to AQP4-IgG addition. In some studies, a neutralizing anti-perforin antibody ( $\delta \mathrm{G} 9,10 \mu \mathrm{g} / \mathrm{ml}$, BD Pharmingen, San Jose, CA) was added together with NK cells onto the $\mathrm{CHO}$ cells. In some studies, the RGD-containing peptide RGDS (or control peptide RGES) (200 $\mu$ M, Sigma-Aldrich) [28] was pre-incubated with $\mathrm{CHO}$ cell cocultures for $1 \mathrm{~h}$ prior to AQP4-IgG addition.

\section{Immunofluorescence}

In some experiments, a fixable red-fluorescent dead-cell stain (L23102, amine-reactive dye, Invitrogen, Eugene, OR) at 1:1000 dilution was added $30 \mathrm{~min}$ prior to cell fixation. Cells were then rinsed in PBS and fixed with $4 \%$ paraformaldehyde (PFA) for $15 \mathrm{~min}$. After fixation, cells were blocked for $1 \mathrm{~h}$ with $1 \%$ BSA and $0.1 \%$ Triton-X100 in PBS, and incubated with primary antibodies. Brains were cut as $7-\mu \mathrm{m}$-thick frozen sections, and blocked in the same buffer before immunostaining. Cultures and brain sections were incubated at $4{ }^{\circ} \mathrm{C}$ overnight with antibodies against AQP4 (sc-20812, 1:200, Santa Cruz Biotechnology, Dallas, TX), AQP4 (sc-9888, 1:200, Santa Cruz Biotechnology, Dallas, TX), C1q (ab71940, 1:50, abcam, Cambridge, MA), C5b-9 (ab55811, 1:200, abcam, Cambridge, MA), GFAP (AB5541, 1:1000; Millipore, Burlington, MA), MAP2 (PA5-17646, 1: 100 , Thermo Fisher Scientific, Rockford, IL), perforin ( $\delta G 9$, 556434, 1:100, BD Pharmingen, San Jose, CA), NeuN (ABN78, 1:200, Millipore, Burlington, MA), Olig2 (sc48817, 1:100, Santa Cruz Biotechnology, Dallas, TX) or GFP (MA1-952, 1:20, Thermo Fisher Scientific, Rockford, IL) followed by $1 \mathrm{~h}$ incubation with appropriate speciesspecific Alexa Fluor-conjugated secondary antibody $(5 \mu \mathrm{g} /$ $\mathrm{ml}$ each, Invitrogen, Camarillo, CA). Sections and coverslips were mounted with ProLong Gold antifade reagent (P36931, Thermo Fisher Scientific, Rockford, IL), and immunofluorescence was visualized on a Nikon confocal microscope using a $20 x / 0.5$ N.A., $60 x / 1.25$ N.A., or $100 x /$ 1.4 N.A. oil objective lens.

\section{Real-time imaging}

For live-cell real-time imaging, $\mathrm{CHO}-\mathrm{AQP} 4$ / CHO-null cell cocultures were imaged using a 20x, 0.45 NA objective lens on a Nikon Eclipse Ti microscope equipped with an environmental chamber at $37^{\circ} \mathrm{C}$ and $5 \% \mathrm{CO}_{2}$. $\mathrm{CHO}-$ AQP4 cells were loaded with the CellTracker ${ }^{\text {ru }}$ Green CMFDA (C2925, $5 \mu \mathrm{M}$ in HBSS) for $30 \mathrm{~min}$ at $37^{\circ} \mathrm{C}$, cell tracker was removed and cells were replated with unlabeled $\mathrm{CHO}$-null cells overnight before experiments. Control experiments verified that $100 \%$ of $\mathrm{CHO}-\mathrm{AQP} 4$ cells retained the CellTracker label overnight. Cells were then pre-incubated with $5 \mu \mathrm{g} / \mathrm{ml}$ AQP4-IgG for $30 \mathrm{~min}$, which was then washed away prior to imaging. For imaging, cells were then incubated in HBSS containing ethidium homodimer-1 (1 $\mu \mathrm{M}$, Invitrogen, Eugene, OR). Transmitted light (phase-contrast), green and red fluorescence images were obtained sequentially every $2 \mathrm{~min}$ for a $30 \mathrm{~min}$ baseline period and then for $1.5 \mathrm{~h}$ following addition of NK cells.

\section{Mouse studies}

$\mathrm{AQP} 4$ knockout $\left(\mathrm{AQP} 4^{-1-}\right)$ mice used in this study have been described and extensively characterized [35]. Experiments were done on weight-matched wild type and $\mathrm{AQP} 4^{-1-}$ mice on a $\mathrm{CD} 1$ genetic background, generally of age 16-18 weeks. Mice were anesthetized with ketamine $(100 \mathrm{mg} / \mathrm{kg})$ and xylazine $(10 \mathrm{mg} / \mathrm{kg})$ and mounted on a stereotaxic frame. A midline scalp incision was made and a burr hole of diameter $1 \mathrm{~mm}$ was drilled in the skull $0.5 \mathrm{~mm}$ anterior and $2 \mathrm{~mm}$ lateral to the bregma. A glass pipette with a $40-\mu \mathrm{m}$-diameter tip was inserted $3 \mathrm{~mm}$ deep to infuse $4 \mu \mathrm{g}$ AQP4-IgG (or control IgG) together with $10^{4}$ GFP labeled NK-cells and $3 \mu \mathrm{M}$ dead cell dye ethidium homodimer $(\mathrm{EH}-1)$ at $\sim 1 \mu \mathrm{l} / \mathrm{min}$ for a total volume of $3 \mu \mathrm{l}$. In some experiments, AQP4IgG and NK cells were injected together with RGDS peptide or RGES peptide $(1 \mathrm{mM}, 2 \mu \mathrm{l})$. After $90 \mathrm{~min}$, mice were anesthetized and perfused through the left cardiac ventricle with $100 \mathrm{ml}$ PBS and then $100 \mathrm{ml}$ of $4 \%$ PFA in PBS. Brain were post-fixed overnight in 4\% PFA and cryoprotected in $20 \%$ sucrose for cutting $7-\mu \mathrm{m}$-thick sections on a cryostat.

\section{Image analysis}

To quantify the fraction of dead cells surrounding AQP4 expressing cells, low magnification (5x) images were used. ImageJ software was used to draw concentric circles of $100 \mu \mathrm{m}, 200 \mu \mathrm{m}$ and $300 \mu \mathrm{m}$ radius around single, isolated AQP4-expressing cells. Dead and total cells within each circle were counted from the red fluorescence and transmitted light images, respectively.

\section{Statistics}

Data are presented as mean \pm S.E.M. Statistical analysis and graphing were performed with GraphPad Prism 6 software. Statistical comparisons were made using the two-way ANOVA for comparisons within a group data set. 


\section{Results}

\section{Complement bystander cytotoxicity in $\mathrm{CHO}$ cell} cocultures

A CHO cell coculture system was established to study bystander cytotoxicity mechanisms. $\mathrm{CHO}$ cells were chosen for initial model studies because of their rapid growth on uncoated plastic or glass, strong plasma membrane AQP4 expression following transfection, and ability to generate cultures with well-isolated AQP4-expressing cells surrounded by bystander cells. Figure 1a shows AQP4 immunofluorescence, with DAPI counterstain, of cocultures containing AQP4-expressing $\mathrm{CHO}$ cells (CHO-AQP4) and non-transfected $\mathrm{CHO}$ cells (CHO-null) at different cell number ratios. At lower ratios, the $\mathrm{CHO}-\mathrm{AQP} 4$ cells were generally well-separated and surrounded by $\mathrm{CHO}-$ null cells. Occasionally, two adjacent $\mathrm{CHO}-\mathrm{AQP} 4$ cells were seen as a consequence of cell division that occurred between the time of plating and experiment.

A CHO-AQP4 to CHO-null cell ratio of 1:50 was used to study complement bystander cytotoxicity, which was done initially as a reference to compare with ADCC bystander experiments. To study complement bystander cytotoxicity, cocultures were incubated with AQP4-IgG and human complement $(\mathrm{HC})$ for $2 \mathrm{~h}$ with a fixable dead cell dye added at $1.5 \mathrm{~h}$ (Fig. 1b, top). Figure $1 \mathrm{~b}$ (bottom, left panel) shows several red-stained dead CHO-null cells surrounding a dead CHO-AQP4 cell. Dead cells were not seen with control (non-NMO) IgG in place of AQP4-IgG, with AQP4-IgG but without $\mathrm{HC}$, and in CHO-null cells exposed to AQP4-IgG and HC (Figs. 1b, 3 right panels). Figure 1c summarizes the analysis of images from 3 cocultures in which the fraction of dead $\mathrm{CHO}$-null cells was determined at different distances from dead CHO-AQP4 cells. Essentially all dead bystander CHO-null cells were seen within $100 \mu \mathrm{m}$ of dead CHO-AQP4 cells. Time-lapse imaging shows both CHO-AQP4 cells (labeled with green cell tracker) and nearby $\mathrm{CHO}$-null cells were injured, with $\mathrm{EH}-1$ uptake following AQP4-IgG and human complement addition (see Additional file 1: Video S1).

Figure $1 \mathrm{~d}$ shows immunofluorescence of $\mathrm{C} 1 \mathrm{q}$, an early complement protein that binds to the $\mathrm{Fc}$ portion of AQP4-IgG and activates the classical complement pathway, and C5b-9, the terminal membrane attack complex (MAC) that causes cytotoxicity. When cells were exposed to AQP4-IgG and human complement, C1q immunofluorescence was seen only on AQP4-expressing $\mathrm{CHO}$ cells and not on CHO-null cells (as stained with DAPI), whereas C5b-9 immunofluorescence was seen on both CHO-AQP4 cells and nearby $\mathrm{CHO}$-null cells. These results, utilizing a simple model system, support our prior data on complement bystander cytotoxicity obtained in astrocyte-oligodendrocyte and astrocyteneuron cocultures $[19,60]$.

\section{ADCC bystander killing in $\mathrm{CHO}$ cell cocultures}

The $\mathrm{CHO}$ cell coculture model was then used to test whether AQP4-IgG with NK cells could produce ADCC bystander killing in the absence of complement. For these experiments, cocultures were initially coated with AQP4-IgG by incubation and washing (Fig. 2a), which minimized non-specific solution-phase activation of NK cells by unbound IgG. Figure $2 \mathrm{~b}$ shows examples of apparent ADCC bystander killing in which red-stained, dead CHO-null cells were seen preferentially near dead $\mathrm{CHO}-\mathrm{AQP} 4$ cells. Analysis of experiments done in 5 cocultures showed that killing of bystander $\mathrm{CHO}$-null cells occurred largely with $100 \mu \mathrm{m}$ of CHO-AQP4 cells, with some dead cells seen at greater distances up to $300 \mu \mathrm{m}$ (Fig. 2c). Time course studies showed that ADCC bystander killing was observed at $60 \mathrm{~min}$, with little cell killing at $15 \mathrm{~min}$ and killing largely restricted to $\mathrm{CHO}$ AQP4 cells at 30 min (Fig. 2d). Few dead $\mathrm{CHO}$ cells were seen in control studies done in the cocultures when control (non-AQP4) IgG was used in place of AQP4-IgG or when NK cells were not included, or in pure $\mathrm{CHO}$ null cultures exposed to AQP4-IgG and NK cells (Fig. 2e). Bystander injury to $\mathrm{CHO}$-null cells nearby $\mathrm{CHO}$ AQP4 cells was also seen using serum from two seropositive NMO patients instead of the recombinant AQP4-IgG antibody (Fig. 2f).

Studies were done to investigate potential mechanisms of ADCC bystander killing by AQP4-IgG and NK cells. In $\mathrm{CHO}$ cell cocultures exposed to AQP4-IgG and NK cells, perforin immunostaining was seen on both AQP4positive $\mathrm{CHO}$ cells and AQP4-negative $\mathrm{CHO}$-null bystander cells (Fig. 3a), suggesting the involvement of perforin release in bystander cell killing. Time-lapse imaging was done to visualize the events during ADCC bystander killing. For these studies AQP4-expressing $\mathrm{CHO}$ cells were pre-labeled with cell tracker green fluorescent marker (with $\mathrm{CHO}$-null cells not labeled) in order to identify them during real-time imaging. Ethidium homodimer was included, which is rapidly taken up and becomes fluorescent in injured cells. Figure $3 \mathrm{~b}$ shows images from a time-lapse video (see Additional file 2: Video S2). At $30 \mathrm{~min}$ NK cell activation was seen on a green $\mathrm{CHO}-\mathrm{AQP} 4$ cell, which became stained red at $120 \mathrm{~min}$. An activated NK cell was seen at $40 \mathrm{~min}$ to move to nearby bystander cells, which became stained red at $90 \mathrm{~min}$. Examination of $>20$ bystander killing events in multiple time-lapse images revealed that in all cases bystander killing involved physical contact between activated NK cells and bystander cells.

\section{ADCC bystander killing in in vitro models of NMO}

To investigate whether ADCC bystander killing, as demonstrated in the AQP4-IgG-exposed $\mathrm{CHO}$ coculture / NK cell model system, can occur in cell types that are 


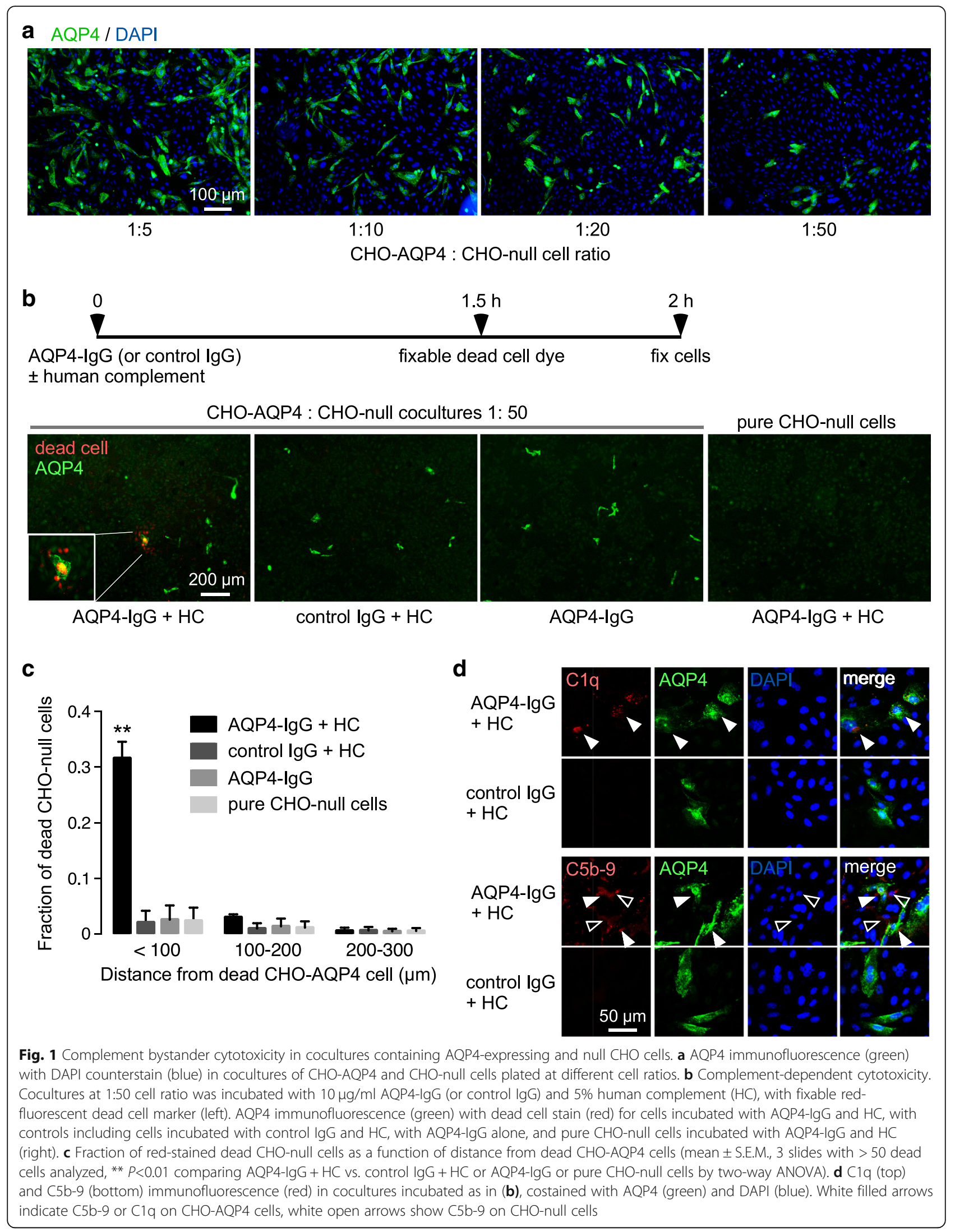




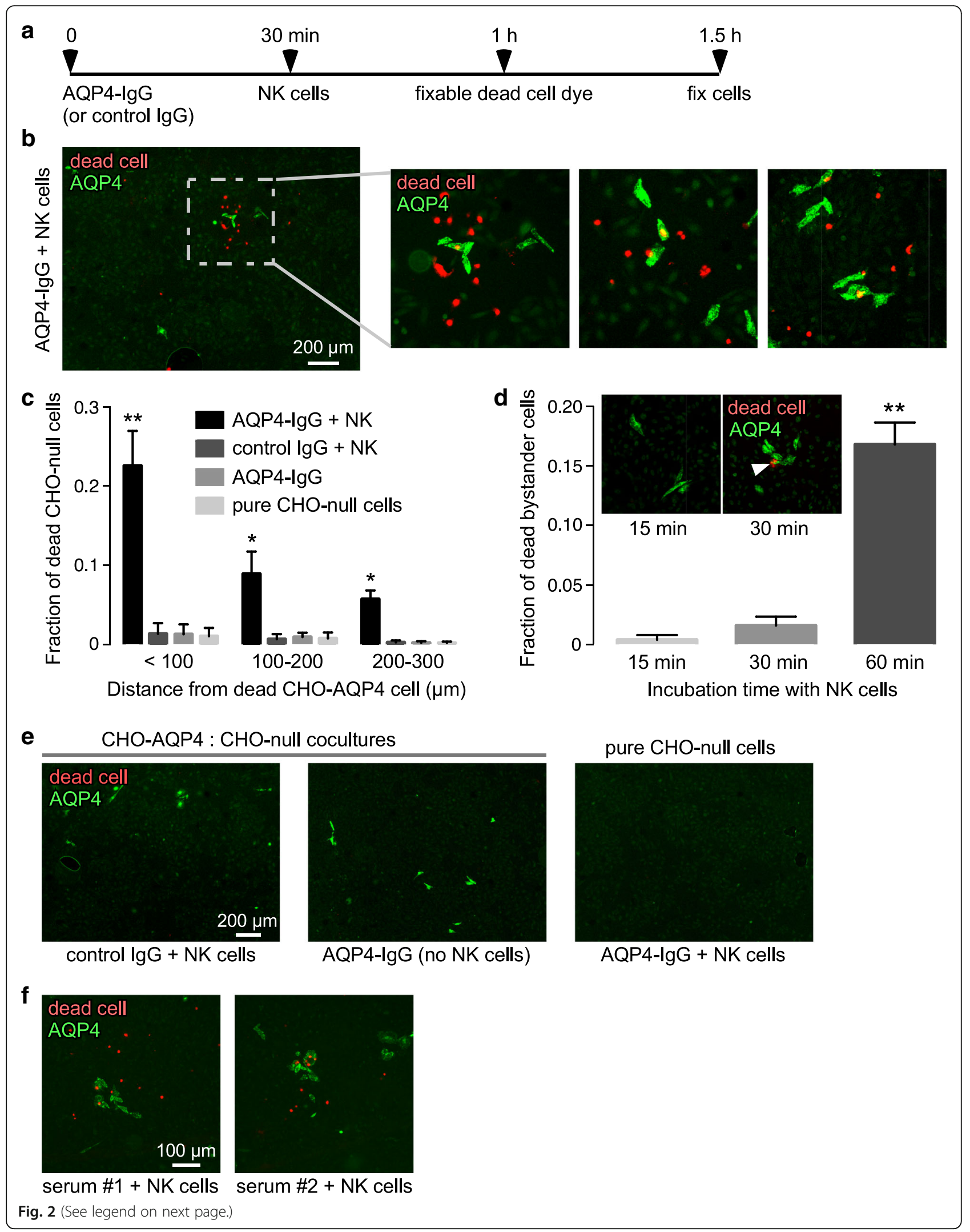


(See figure on previous page.)

Fig. 2 ADCC bystander killing in cocultures containing AQP4-expressing and null CHO cells. a Cocultures at 1:50 CHO-AQP4:CHO-null cell ratio were pre-incubated for 30 min with AQP4-lgG (or control lgG) then washed followed by addition of NK cells with a fixable dead cell stain at 30 min prior to fixation. b AQP4 immunofluorescence (green) with dead cell stain (red) at low magnification (left) in cocultures incubated with $5 \mu \mathrm{g} /$ ml AQP4-lgG and NK cells at an effector:target cell ratio of 5:1. Three fields at high magnification are shown (right). $\mathbf{c}$ Fraction of red-stained, dead CHO-null cells as a function of distance from dead CHO-AQP4 cells (mean \pm S.E.M., 5 slides with $>80$ dead cells analyzed, ${ }^{* *} P<0.01,{ }^{*} P<0.05$ comparing AQP4-lgG + NK vs. control lgG + NK or AQP4-lgG or pure CHO-null cells by two-way ANOVA). $\mathbf{d}$ Fraction of dead bystander cells, as in (c), as a function of incubation time with NK cells (mean \pm S.E.M., 5 slides, ${ }^{* *} P<0.01$ by unpaired $t$ test). Inset shows representative fields at 15 min and $30 \mathrm{~min}$. White filled arrow indicates dead CHO-AQP4 cell at $30 \mathrm{~min}$. e Control studies including CHO-AQP4 and CHO-null cocultures incubated with $5 \mu \mathrm{g} / \mathrm{ml}$ control lgG and NK cells at an effector:target cell ratio of 5:1, with AQP4-lgG alone, and pure CHO-null cells incubated with AQP4-lgG and NK cells. f Cocultures were incubated with NK cells and 1\% serum from two seropositive NMO patients, and immunostained as in panel (b)

relevant to NMO neuropathology, experiments were done in primary astrocyte-neuron cocultures in which AQP4 is expressed on astrocytes but not on neurons $[19,42]$. Cells were exposed to AQP4-IgG and NK cells for $2 \mathrm{~h}$. Figure $4 \mathrm{a}$ shows dead, red-stained MAP2positive neurons nearby dead GFAP-positive astrocytes. Minimal killing was found in cocultures incubated with control IgG and NK cells or AQP4-IgG without NK cells. Figure $4 \mathrm{~b}$ summarizes the fraction of dead neurons at different distances from the center of dead astrocytes, showing preferential killing of neurons within $300 \mu \mathrm{m}$ of dead astrocytes. Perforin deposition was seen on both astrocytes and nearby neurons (Fig. 4c).

ADCC bystander killing studies were also done in the $\mathrm{CHO}$ cell coculture system, but using neutrophils instead of NK cells. Freshly isolated human neutrophils were incubated with $\mathrm{CHO}$ cell cocultures for $1 \mathrm{~h}$ following AQP4-IgG exposure. Figure 4d (left panel) shows bystander killing of CHO-null cells (as stained with DAPI) nearby dead $\mathrm{CHO}-\mathrm{AQP} 4$ cells (AQP4 stained), with the inset confirming CD66b-positive neutrophil identity. Figure $4 \mathrm{~d}$ (three center panels) shows that exposure of $\mathrm{CHO}$ cell cocultures to neutrophils and AQP4-IgG produces bystander killing by an ADCC mechanism, with killing not seen with neutrophils alone or in pure $\mathrm{CHO}$ null cell cultures. Figure 4d (right panel) summarizes the fraction of dead $\mathrm{CHO}$-null cells at different distances from the center of dead AQP4-expressing $\mathrm{CHO}$ cells, showing preferential killing of $\mathrm{CHO}$-null cells within $100 \mu \mathrm{m}$ of dead CHO-AQP4 cells.

\section{ADCC bystander killing in a mouse model of NMO}

We previously reported an ADCC model of NMO in mice in which intracerebral administration of AQP4-IgG and NK cells produced astrocytopathy and inflammation $[45,47]$. Because endogenous complement activity in mouse is low $[11,46]$, ADCC studies in mice are not confounded by complement activation. To investigate whether ADCC bystander killing occurs in mouse brain in vivo, AQP4-IgG and a small number of GFP-labeled NK cells were injected into mouse brain together with dead cell dye ethidium homodimer-1 (EH-1) (Fig. 5a).
Brains were fixed in situ and frozen sections were examined by confocal microscopy at high magnification to resolve astrocytes, NK cells and dead cells using GFAP to identify astrocytes and a GFP antibody to identify NK cells. Figure 5b shows many dead cells (EH-1 positive) near the needle tract in wild type mice receiving AQP4IgG and GFP-NK cells. Few or no dead cells were seen with injection of control IgG and NK cells, with AQP4IgG alone, or when AQP4-IgG and NK cells were injected into $\mathrm{AQP} 4^{-/-}$mice.

At high magnification, red-stained dead cells were seen, which included GFAP immunostained astrocytes (white) in contact with GFP immunostained GFP-NK cells (green), as well as some nearby dead cells that were not stained with GFAP antibody and hence not astrocytes (Figs. 5c, 2 right panels). Cell death was not seen in $\mathrm{AQP} 4^{+/+}$mice receiving control IgG and NK cells or $\mathrm{AQP}^{-/-}$mice receiving AQP4-IgG and NK cells (Fig. $5 \mathrm{c}$, two right panels). Figure $5 \mathrm{~d}$ summarizes the fraction of dead astrocytes associated with 0,1 and 2 or more dead nearby (within $100 \mu \mathrm{m}$ ) bystander cells, showing dead bystander cells associated with more than half of the dead astrocytes. To identify dead bystander cells, NeuN was used as a neuron marker and Olig2 as oligodendrocyte marker, with AQP4 as the astrocyte marker. Figure 5e (left) shows bystander cell killing using AQP4 as the astrocyte marker. Figure $5 \mathrm{e}$ (center and right) shows examples of dead neurons and oligodendrocytes near dead astrocytes.

\section{Small molecule and peptide inhibitors of ADCC bystander killing}

We tested three potential inhibitors of ADCC in the NK cell / $\mathrm{CHO}$ coculture model, and one inhibitor in mice in vivo. To confirm that bystander killing in the in vitro model is perforin mediated, $\mathrm{CHO}$ cell cocultures were incubated with concanamycin A (CMA) or anti-perforin antibody (Fig. 6a). CMA inactivates perforin prior to release by increasing granule $\mathrm{pH}[29,65]$. Anti-perforin antibody blocks target cell killing by NK cells by a mechanism involving impaired perforin binding to the target cell surface [30]. We found near-complete prevention of 
a
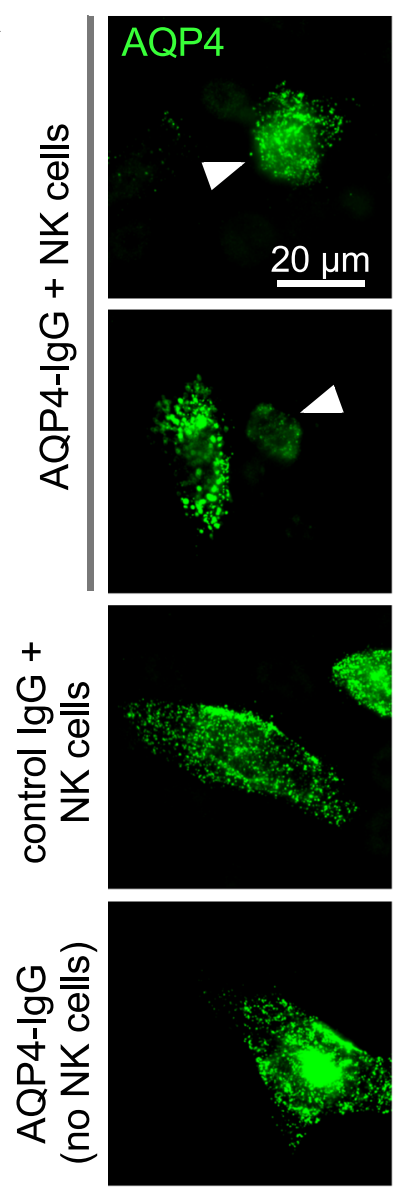

b
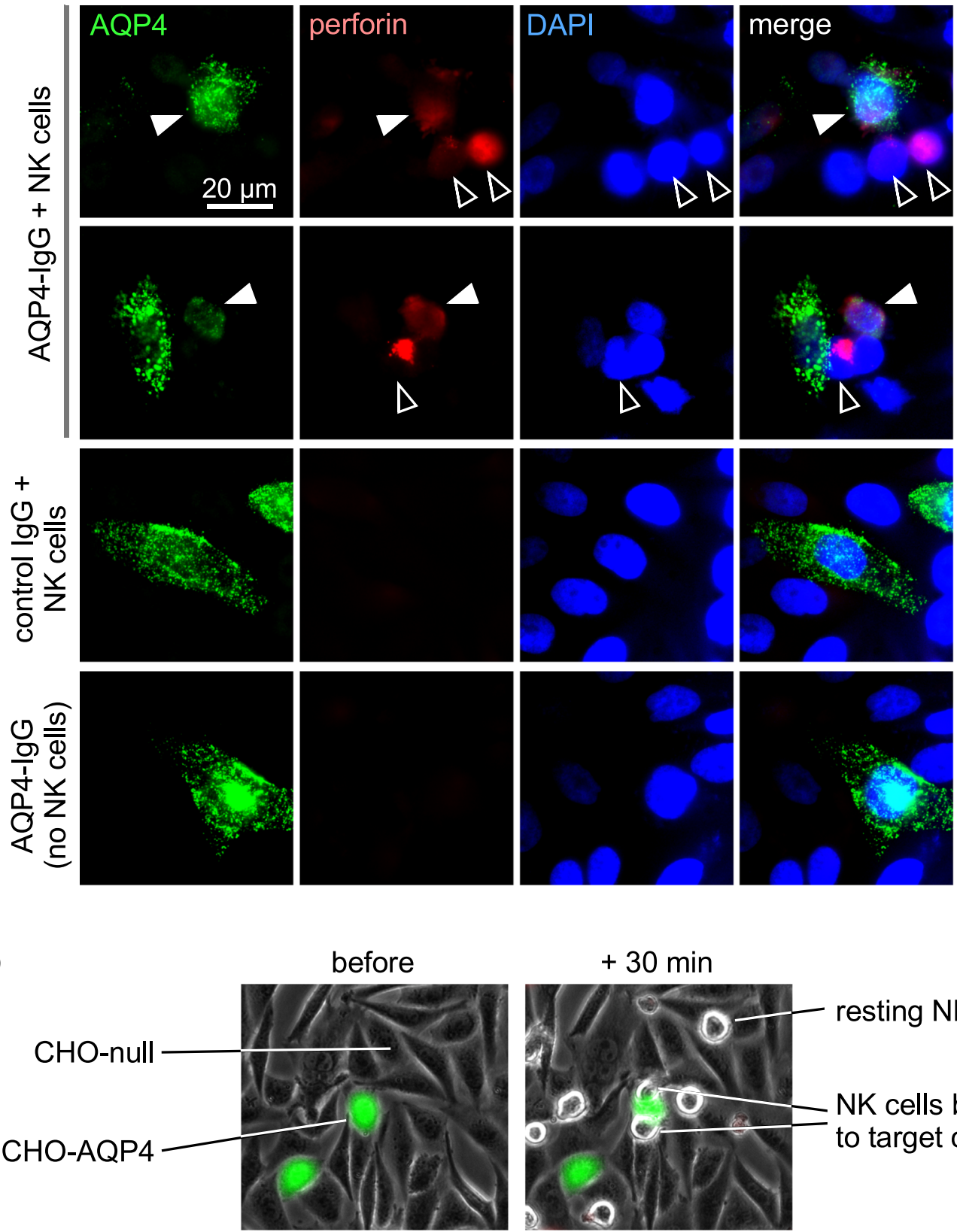

$+30 \min$

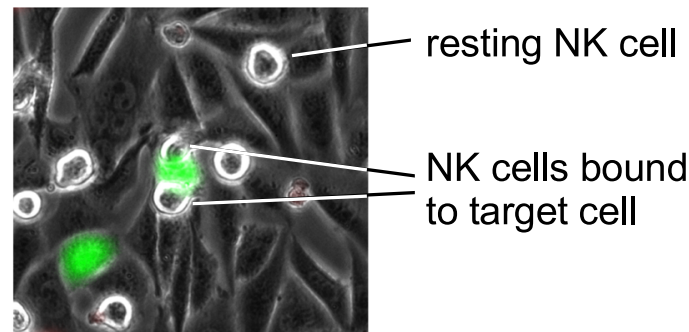

$+40 \min$

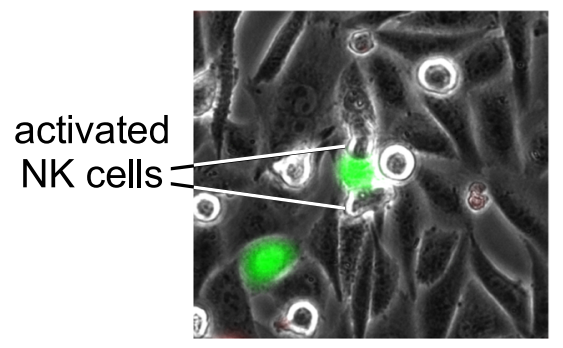

$+90 \min$

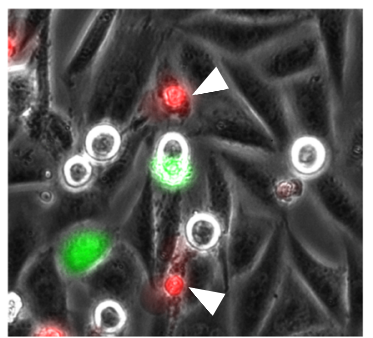

$+120 \min$

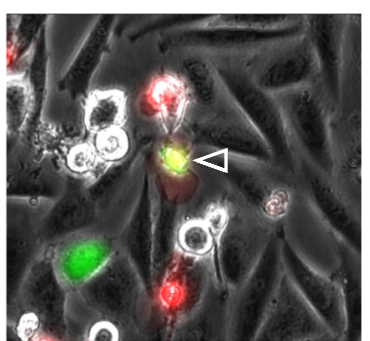

Fig. 3 (See legend on next page.) 
(See figure on previous page.)

Fig. 3 Mechanism of ADCC bystander killing. a Perforin immunofluorescence of CHO-AQP4 and CHO-null cocultures after pre-coating with AQP4IgG and incubation NK cells, as in Fig. 2b, with controls including control IgG and NK cells, and AQP4-lgG alone. White filled arrows indicate perforin on AQP4-expressing $\mathrm{CHO}$ cells, white open arrows show perforin on $\mathrm{CHO}$-null cells. $\mathbf{b}$ Time-lapse imaging of coculture of CHO-AQP4 cells (labeled green with cell tracker) and CHO-null cells, pre-incubated for 30 min AQP4-lgG, then at indicated times after NK cell addition (for explanation see text and Additional file 2: Video S2)

target and bystander cell killing by CMA or antiperforin antibody (Fig. 6b), supporting the conclusion that perforin is the major cytotoxic granule component in the model system studied here.

If ADCC bystander killing involves physical movement of an activated NK cell from a target $\mathrm{CHO}-\mathrm{AQP} 4$ cell to a nearby bystander cell, then inhibition of NK cell adhesion to target cells might reduce bystander cell killing. NK-cell mediated ADCC can involve LFA-1/ICAM-1 interaction [7, 61], though $\mathrm{CHO}$ cells do not express ICAM-1 at significant levels $[5,56]$, nor do astrocytes under resting conditions [1, 58]. Integrin-mediated

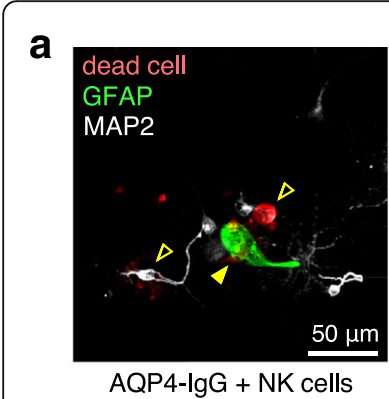

b

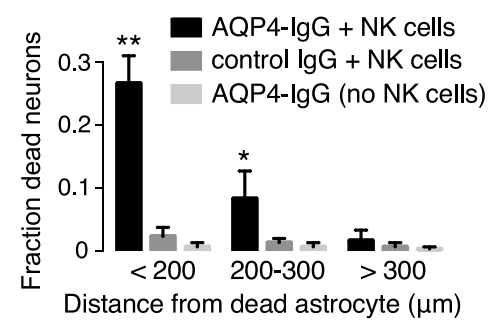

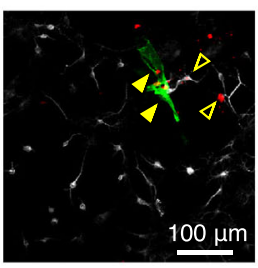

AQP4-IgG + NK cells

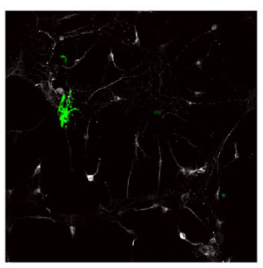

control lgG + NK cells AQP4-lgG (no NK cells)

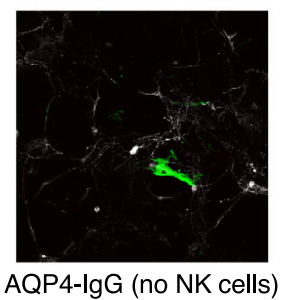

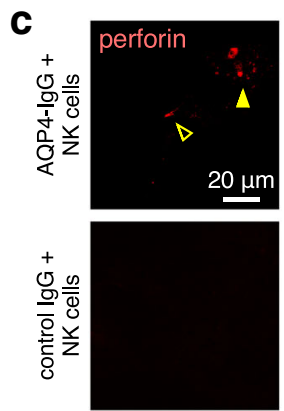
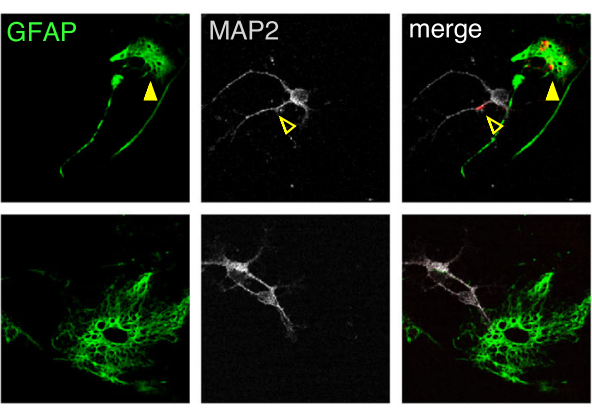

d
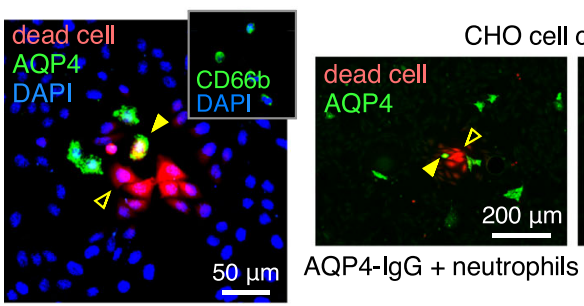

AQP4-IgG + neutrophils
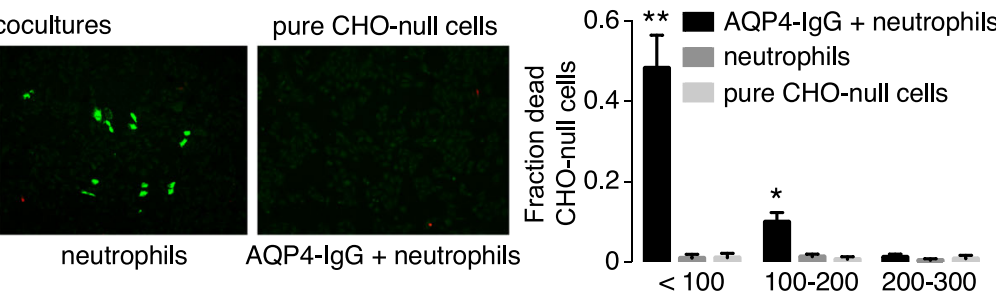

Distance from dead CHO-AQP4 cell $(\mu \mathrm{m})$

Fig. 4 ADCC bystander killing in astrocyte-neuron cocultures. a Astrocyte-neuron cocultures following 30 min pre-coating with AQP4-lgG and $2 \mathrm{~h}$ incubation with NK cells at an effector:target cell ratio of 5:1, with fixable dead cell marker added for the final 30 min. GFAP (astrocyte) and MAP2 (neuron) immunofluorescence, with dead cells stained red, shown at high (left) and low (right) magnifications. Yellow filled arrows indicate dead astrocytes, yellow open arrows show dead neurons. b Fraction of dead neurons at different distances from the center of dead astrocytes (mean \pm S.E.M., 3 slides with $>30$ dead cells analyzed, ${ }^{*} P<0.01,{ }^{*} P<0.05$ comparing AQP4-lgG + NK vs. control lgG + NK or AQP4-lgG without NK cells by two-way ANOVA). c Perforin immunofluorescence (red) of cocultures treated as in a. with GFAP (green) and MAP2 (gray) immunofluorescence. Yellow filled arrows indicate perforin on astrocytes, yellow open arrows show perforin on neurons. $\mathbf{d}$ AQP4 immunofluorescence (green) with dead cell stain (red) and DAPI (blue) at high (left) and low (center) magnifications in CHO-AQP4 and CHO-null cocultures following $5 \mathrm{\mu g} / \mathrm{ml} \mathrm{AQP4-lgG}$ and neutrophils at an effector:target cell ratio of 5:1. Yellow filled arrows indicate dead CHO-AQP4 cells, yellow open arrows show dead CHO-null cells. (Right) Fraction of dead CHO-null cells at different distances from the center of dead CHO-AQP4 cells (mean \pm S.E.M., 3 slides with $>50$ dead cells analyzed, ${ }^{*} P<0.01,{ }^{*} P<0.05$ comparing AQP4-lgG + neutrophils vs. neutrophils or pure CHO-null cells by two-way ANOVA) 


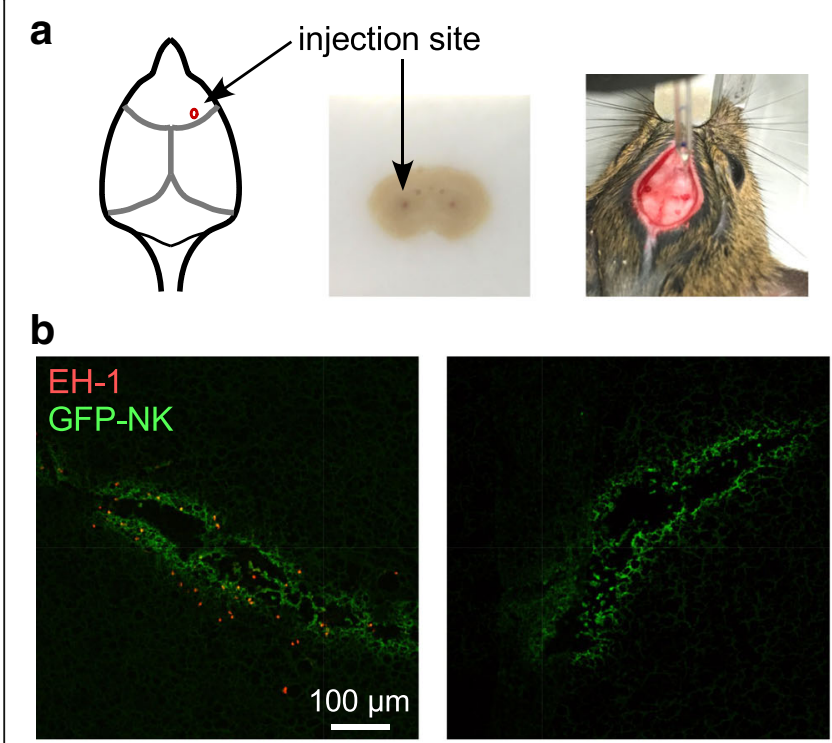

$\mathrm{AQP}^{+/+} / \mathrm{AQP} 4-\mathrm{IgG}+\mathrm{NK} \quad \mathrm{AQP}^{+/+} /$contol lgG $+\mathrm{NK}$

C

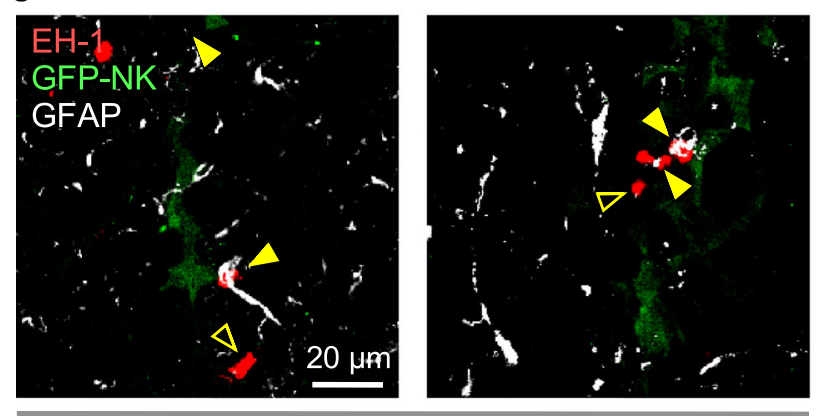

$\mathrm{AQP}^{+/+} / \mathrm{AQP} 4-\operatorname{lgG}+\mathrm{NK}$

d

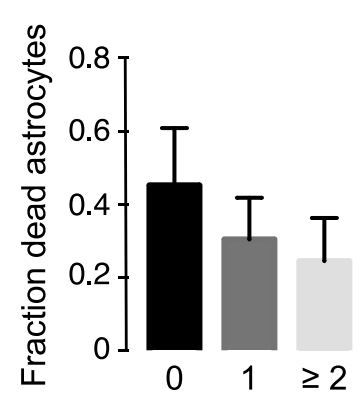

Number of dead bystander cells e

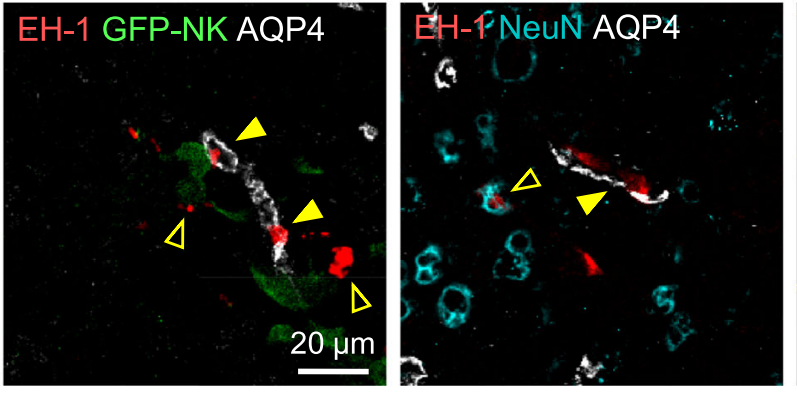

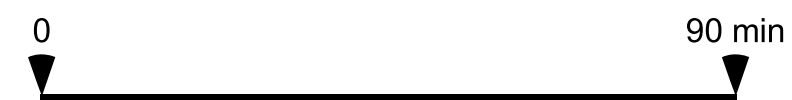

sacrifice

AQP4-IgG (or control lgG) + EH-1

\pm GFP-labelled NK cells

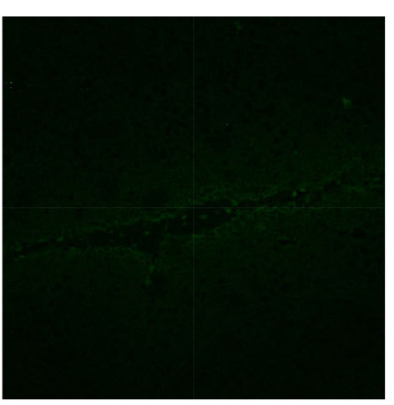

$\mathrm{AQP}^{+/+} / \mathrm{AQP4}-\lg \mathrm{G}$

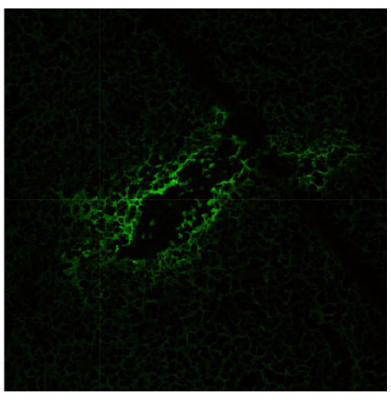

AQP4-/- / AQP4-lgG + NK
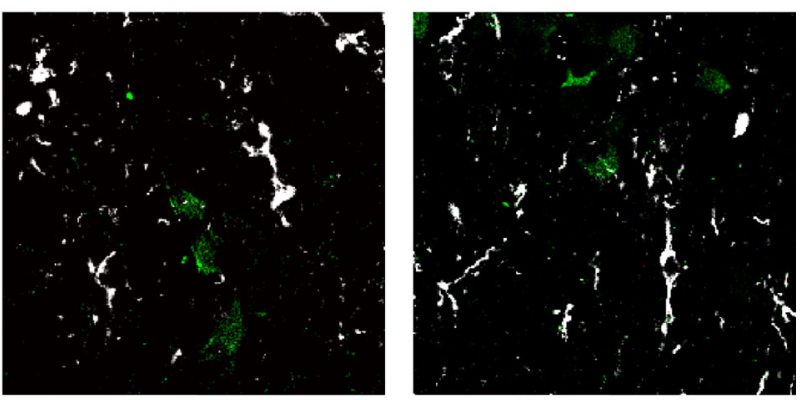

$\mathrm{AQP}^{+/+} /$contol $\lg \mathrm{G}+\mathrm{NK}$

Fig. 5 ADCC bystander killing in mouse brain. a Mice were administered AQP4-lgG or control lgG (4 $\mu \mathrm{g})$ and dead cell stain EH-1 (3 $\mu$ M) with or without GFP-NK cells ( $10^{4}$ cells) by intracerebral injection and sacrificed at $90 \mathrm{~min}$. b Low-magnification confocal microscopy showing dead cells (red EH-1 fluorescence) and green immunostained NK cells. c High-magnification confocal images of $\mathrm{AQP} 4^{+/+}$or $\mathrm{AQP} 4^{-/-}$mice treated as in a, showing dead cells (red), GFP-NK cells (green), and astrocytes (white). Yellow filled arrows show dead astrocytes, yellow open arrows show dead bystander cells. $\mathbf{d}$ Fraction of dead astrocytes associated with 0, 1 or $\geq 2$ dead bystander cells (mean \pm S.E.M., 5 slides with $>30$ dead cells analyzed). e High-magnification confocal images of mice treated as in a, with indicated stain combinations. Yellow filled arrows show dead astrocytes, yellow open arrows show dead bystander cells some of which were NeuN-positive (neurons) or Olig2-positive (oligodendrocytes) 


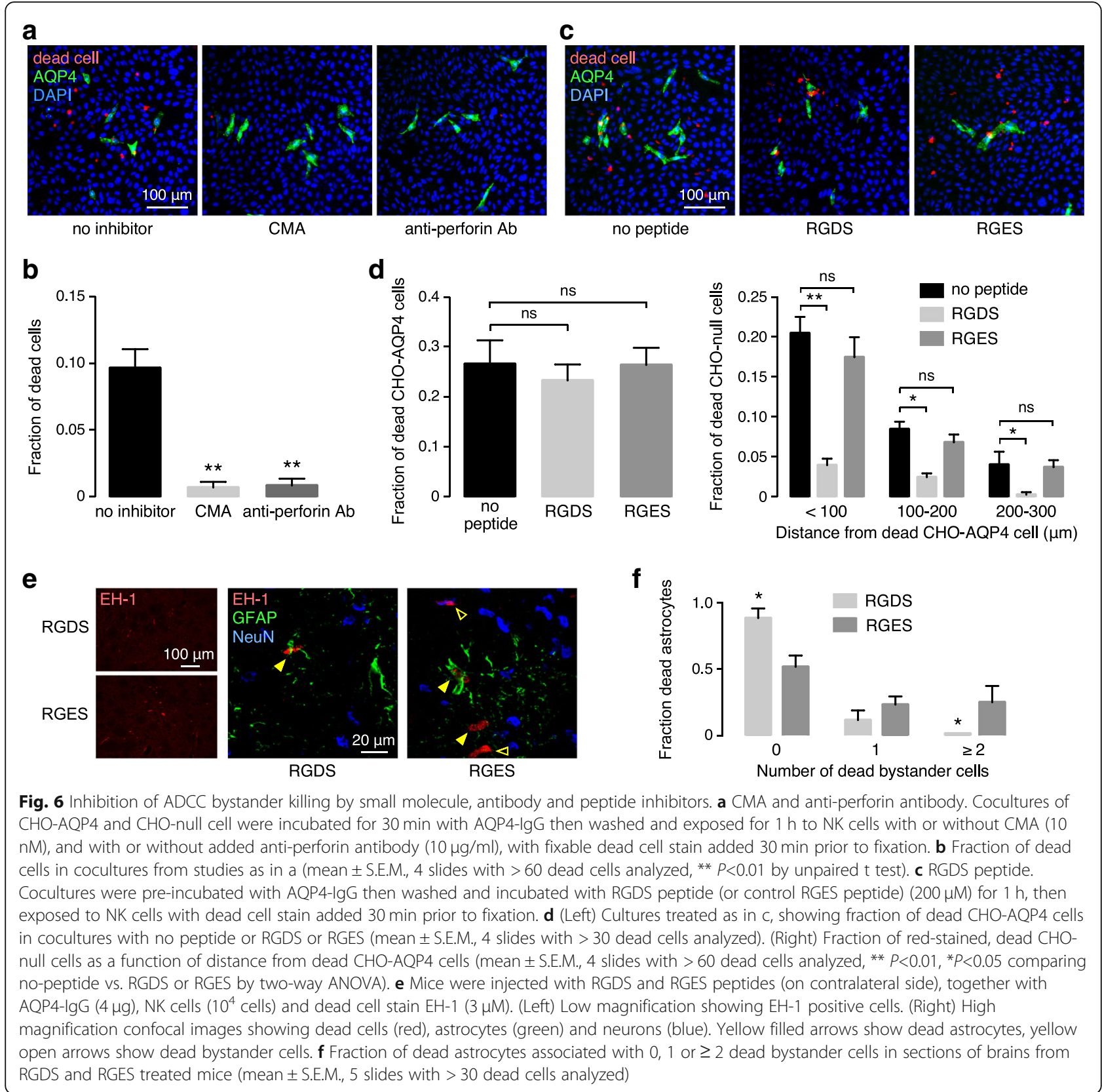

signaling may facilitate ADCC in the absence of ICAM1 [3]. As integrin adhesion generally involves the minimal integrin binding motif Arg-Gly-Asp (RGD) [28], RGD-containing peptides can block integrin-associated cell adhesion $[8,13,17,50]$ and inhibit degranulation of cytotoxic lymphocytes [18]. CHO cells express multiple integrins, including $\alpha v \beta 3$ and $\alpha \operatorname{IIb} \beta 3$, which can be blocked by RGDS peptide [14]. Figure 6c shows reduced ADCC bystander killing by Arg-Gly-Asp-Ser (RGDS) peptide preincubation, without significant effect of control peptide (Arg-Gly-Glu-Ser, RGES). The peptides did not impair killing of CHO-AQP4 target cells (Fig. 6d, left panel). Figure 6d (right panel) summarizes the fraction of dead CHO-null cells at different distances from the center of dead AQP4-expressing $\mathrm{CHO}$ cells, showing the RGDS preferentially reduces bystander killing within $100 \mu \mathrm{m}$ of dead CHO-AQP4 cells.

As intracerebral injection of RGDS peptides has demonstrated utility in treating N-methyl-D-aspartate-mediated brain excitotoxicity [43], we studied RGDS action in the mice in which the peptide (or control RGES) was administered by intracerebral injection together with AQP4-IgG and NK cells. At low magnification, staining with EH-1 was much reduced with RGDS peptide 
compared with control RGES peptide in the contralateral hemisphere (Fig. 6e, left). Higher magnification (right panel) shows that the dead cells with RGDS peptide consisted mainly of GFAP-immunopositive astrocytes, whereas many GFAP-negative cells were killed with control peptide, some of which were NeuN-positive neurons. Quantification of images in Fig. $6 f$ showed a significant redistribution of the cell killing profile to astrocytes vs. bystander cells with RGDS peptide.

\section{Discussion}

The results here extend prior evidence on ADCC as a complement-independent mechanism of astrocyte injury in AQP4-IgG-seropositive NMOSD [34, 45, 47, 67, 68]. We show ADCC bystander killing as an additional pathogenesis mechanism linking AQP4-IgG binding to AQP4 on astrocytes with injury to other cell types in the central nervous system, such as neurons and oligodendrocytes, and consequent neurological deficit. ADCC bystander killing was demonstrated in AQP4-transfected $\mathrm{CHO}$ cell / null cell and astrocyte / neuron co-cultures using NK cells or neutrophils as the effector cells. Distance-dependent bystander cell killing and perforin immunofluorescence provided evidence in support of an ADCC bystander mechanism. The range of bystander killing in ADCC extended well beyond that seen with complement bystander injury in the same coculture system, with killing seen to $300 \mu \mathrm{m}$ with ADCC compared to $<100 \mu \mathrm{m}$ with $\mathrm{CDC}$, demonstrating ADCC bystander injury has a greater range of action than complement bystander injury. Time-lapse imaging revealed NK cell activation upon binding to AQP4-IgG on CHO-AQP4 cells and physical movement to nearby cells, producing sequential attack of both the target and bystander cells in a contact-dependent manner. This movement of activated NK cell leads to a greater distance range for ADCC bystander killing than that for complement bystander killing. Within the distance range of ADCC bystander effect, whether a particular bystander cell is killed depends on contact with an activated NK cell with remaining cytotoxic granules and effective delivery of granule contents. Therefore, only a fraction of bystander cells are killed in a stochastic manner within the effective distance range of ADCC bystander killing.

Figure 7 depicts potential mechanisms of ADCC bystander killing in NMO. AQP4-IgG binds to AQP4 on astrocytes, which allows binding and activation of NK cells through Fcy receptors. Activated NK cells can induce bystander cell injury by several mechanisms, including: (i) targeted lytic protein secretion onto immediately adjacent bystander cells following activation; (ii) sequential attack of target cell followed by release and binding/attack of a nearby bystander cell; and (iii) release of soluble granule contents following activation that then diffuse through the extracellular medium and are deposited on nearby cells. Cytotoxic lymphocytes such as NK cells and cytotoxic Tlymphocytes store a variety of cytotoxic proteins within lytic granules, including perforin and granzyme, which are released after antigen-stimulated degranulation [59]. Target cell death relies on the diffusion of the secreted cytolytic proteins through the extracellular matrix to reach their target [48]. Perforin creates large pores on the plasma membrane of target cells, similar to membrane attack complex in complement-dependent cytotoxicity, which facilitate access of granzyme to the cytosol and subsequent cell lysis [64].

Off-target deposition of perforin by activated NK cells has been shown to injure bystander cells in other systems. Co-stimulation of Fcy receptors (CD16) and LFA1 was demonstrated to mediate cell specificity and reduce bystander killing of non-adherent Drosophila S2 cells [9]. In contrast, NK cells activated by CD16 alone, without LFA-1 co-stimulation, trigger bystander cell lysis by non-directional secretion of lytic granules [26]. In our experiments, NK cells were activated by AQP4-IgG coated cells by $\mathrm{CD} 16$ alone, as $\mathrm{CHO}$ cells do not endogenously express LFA-1 ligands, suggesting nonspecific release of perforin and local killing of bystander cells. However, by time-lapse imaging, we found that NK cells sequentially kill CHO-AQP4 cells followed by binding to and killing of nearby null cells, and that integrin blockade with an RGD peptide reduced bystander killing. This finding supports a modified mechanism of bystander killing in which sequential binding to bystander cells by CD16-activated NK cells causes targeted degranulation and cell death, consistent with data showing that NK cells induce serial killing at a single-cell level [15]. Other studies reported that killing of a target cell requires only one-hundredth of the total lytic granule content of an NK cell [22], which make them capable of disengaging from one target cell to serially kill additional target cells. The inhibition of cell killing by CMA and anti-perforin antibody suggests that both target and bystander cell lysis is perforin-dependent; however, it is possible that additional Fas-dependent cell killing may occur on longer time scales [2].

It remains to be determined if the 'serial bystander' killing described here is a general phenomenon or specific to AQP4-IgG activated NK cells. The M23 isoform of AQP4 forms large semi-crystalline macromolecular aggregates called orthogonal arrays of particles (OAPs) that are unique to this protein and that can bind several AQP4-IgG antibodies simultaneously [16, 44]. Though $\mathrm{CDC}$ requires $\mathrm{AQP} 4$ aggregation into OAPs for multivalent interaction between AQP4-IgG and complement protein $\mathrm{C1q}, \mathrm{ADCC}$ is relatively insensitive to the $\mathrm{AQP} 4$ aggregation state [44]. Large OAPs can be removed from 


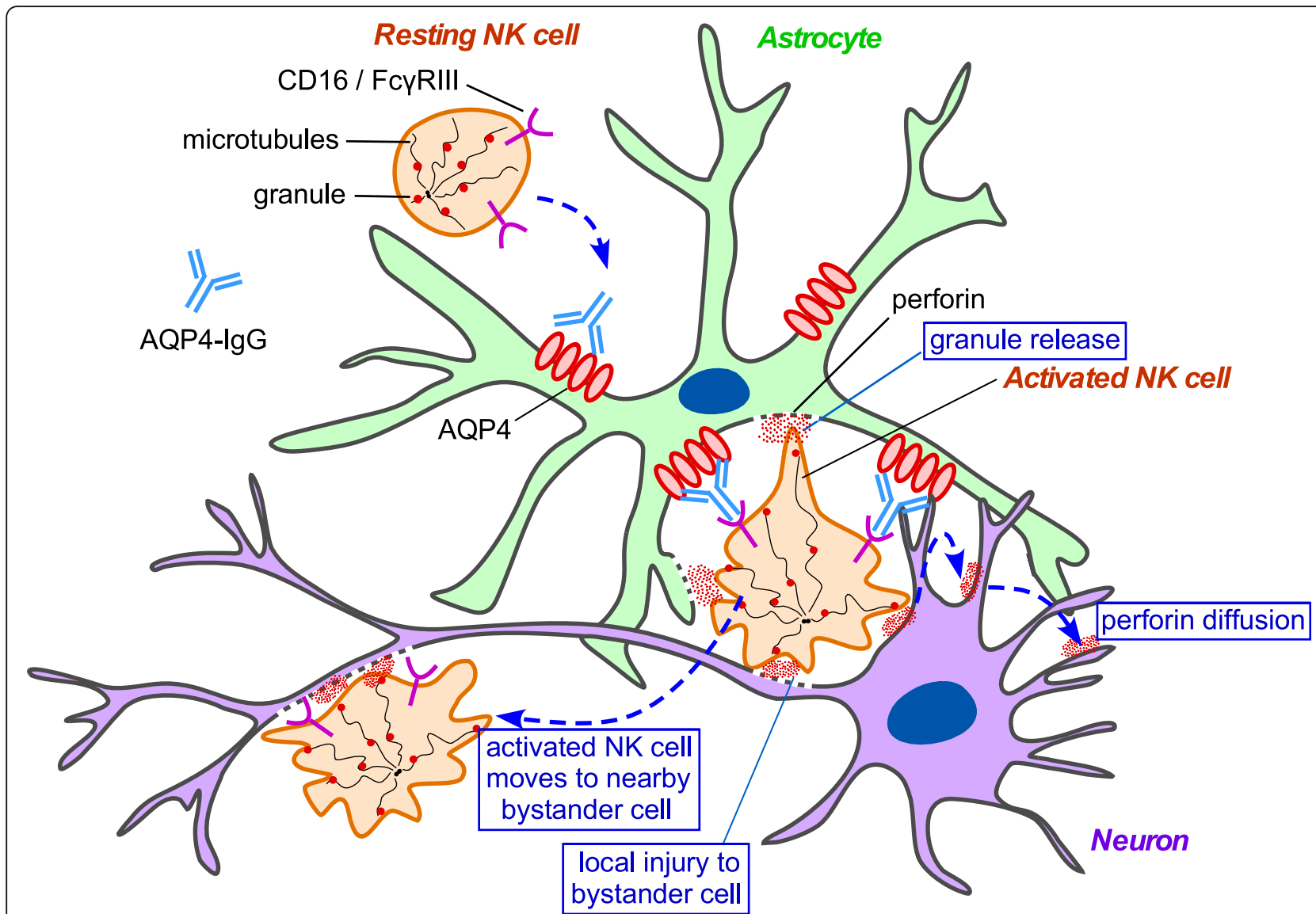

Fig. 7 Proposed mechanisms of ADCC bystander killing in AQP4-IgG seropositive NMOSD. Diagram shows AQP4-lgG binding to AQP4 on astrocytes, with binding and activation of NK cells through Fcy receptors. Activated NK cells can induce bystander cell damage via three mechanisms, including: (i) targeted lytic protein secretion onto immediately adjacent bystander cells following activation; (ii) sequential attack of target cells followed by release and binding/attack of a nearby bystander cell; and (iii) release of soluble granule contents following activation that then diffuse through the extracellular medium and are deposited on nearby cells

the membrane of cells [57], which might provide a mechanism for sustained signaling via CD16 after NK cell disengagement from an M23-expressing target cell.

Neutrophils, eosinophils and macrophages are abundantly seen in lesions in human seropositive NMOSD [33, 37, 49, 52], with NK cells and cytotoxic Tlymphocytes observed less frequently [51]. Each of these cell types express Fc receptors that can bind to the Fc moiety of AQP4-IgG. Recent studies have shown that neutrophils can mediate ADCC by mechanisms including degranulation of cytotoxic molecules [1] and releasing of neutrophil extracellular traps $[12,55]$, as well as inducing apoptosis [25], autophagy [6] and trogocytosis $[36,62]$. We found here that neutrophils not only cause ADCC, but also ADCC bystander injury, demonstrating target non-specificity as a common feature of multiple ADCC mechanisms in NMO.

Though our results demonstrate complementindependent ADCC bystander killing in in vitro and mouse models of NMO, the study here cannot prove directly that ADCC bystander injury occurs in human seropositive NMO. In order to identify dead bystander cells in vivo, our NMO mouse model necessitated synchronizing injection of AQP4-IgG, NK cells and a dead cell marker and sacrifice at an early time point. Various leukocytes, including granulocytes and NK cells, can be short-lived after their entry into the central nervous system and activation [9], so that their paucity or absence does not rule out a role in NMO disease pathogenesis. Further, the lack of availability of central nervous system tissue during acute $\mathrm{NMO}$ attacks limits the extrapolation of animal data to human NMO. However, the leukocyte infiltration in necrotic lesions in post-mortem NMO samples [33, 37, 49] suggests these cells play a role in widespread tissue damage.

\section{Conclusions}

In conclusion, our results support an ADCC bystander killing mechanism for injury to non-AQP4-expressing cells in the central nervous system following AQP4-IgG 
binding to astrocytes and leukocyte activation through $\mathrm{Fcy}$ receptor interaction. The close proximity and intermingling of astrocytes and their processes with multiple cell types, including neurons and oligodendrocytes, would amplify bystander killing efficiency when compared to in vitro studies done on planar cell monolayers. Unlike complement bystander injury, ADCC bystander injury is independent of cell-specific expression of complement regulator proteins proteins such as CD55 and CD59, and so could produce injury to cell types that are relatively resistant to complement injury. An ADCC bystander injury mechanism would suggest the potential utility of NMO therapies directed against new targets such as perforin and leukocyte co-receptors involved in granule release, as well as adhesion molecules involved in leukocyte-bystander cell interaction.

\section{Additional files}

Additional file 1: Video S1. Complement bystander killing in CHO-

AQP4 and CHO-null cell coculture. Time-lapse imaging showing injured CHO-AQP4 cells (labeled with green cell tracker) and nearby CHO-null cells with uptake of dead cell marker EH-1 (red) following addition of $10 \mathrm{\mu g} / \mathrm{ml} \mathrm{AQP4-IgG}$ and 5\% human complement. Video includes a 30 min baseline recording with AQP4-lgG alone, with human complement added at $30 \mathrm{~min}$. (AVI $3262 \mathrm{~kb}$ )

Additional file 2: Video S2 ADCC bystander killing in CHO-AQP4 and $\mathrm{CHO}$-null cell cocultures. Time-lapse imaging of coculture of $\mathrm{CHO}-\mathrm{AQP} 4$ cells (labeled green with cell tracker) and CHO-null cells, pre-incubated for 30 min with AQP4-IgG, followed by NK cell addition at an effector:target cell ratio of 5:1. Solutions contained dead cell marker EH-1 (red). (AVI $4219 \mathrm{~kb}$ )

\section{Acknowledgments}

We thank Dr. Jeffery Bennett (University of Colorado Denver, Aurora, CO) for providing recombinant monoclonal NMO antibody rAb-53.

\section{Authors' contributions}

TJD performed the in vivo and in vitro experiments and analyzed the data. AJS performed live-cell imaging studies. ASV conceived the study and designed the experiments. All authors contributed to the writing and editing and approved the final manuscript.

\section{Funding}

This work was supported by grants EY13574, DK72517 and DK101373 from the National Institutes of Health and a grant from the Guthy-Jackson Charitable Foundation to ASV, and by grant A2018351S from the ADR program of the BrightFocus Foundation and NIH grant EY029881 to AJS.

\section{Availability of data and materials}

The datasets used and/or analysed during the current study are available from the corresponding author on reasonable request.

\section{Ethics approval}

All animal procedures were approved by the UCSF Institutional Animal Care and Use Committee.

\section{Consent for publication}

N/A

\section{Competing interests}

The authors declare that they have no competing interests.

\section{Author details}

'Departments of Medicine and Physiology, University of California, 1246 Health Sciences East Tower, 513 Parnassus Ave, San Francisco, CA 94143-0521, USA. ${ }^{2}$ Department of Neurology, Second Xiangya Hospital of Central South University, Changsha 410011, Hunan, China.

Received: 28 June 2019 Accepted: 1 July 2019

Published online: 11 July 2019

\section{References}

1. Akiyama H, Kawamata T, Yamada T, Tooyama I, Ishii T, McGeer PL (1993) Expression of intercellular adhesion molecule (ICAM)-1 by a subset of astrocytes in Alzheimer disease and some other degenerative neurological disorders. Acta Neuropathol 85:628-634

2. Ando $\mathrm{K}$, Hiroishi $\mathrm{K}$, Kaneko T, Moriyama T, Muto Y, Kayagaki N, Yagita H, Okumura K, Imawari M (1997) Perforin, Fas/Fas ligand, and TNF-alpha pathways as specific and bystander killing mechanisms of hepatitis C virusspecific human CTL. J Immunol 158:5283-5291

3. Anikeeva N, Steblyanko M, Fayngerts S, Kopylova N, Marshall DJ, Powers GD, Sato T, Campbell KS, Sykulev Y (2014) Integrin receptors on tumor cells facilitate NK cell-mediated antibody-dependent cytotoxicity. Eur J Immunol 44:2331-2339. https://doi.org/10.1002/eji.201344179

4. Asavapanumas N, Ratelade J, Verkman AS (2014) Unique neuromyelitis optica pathology produced in naive rats by intracerebral administration of NMO-lgG. Acta Neuropathol 127:539-551. https://doi.org/10.1007/s00401013-1204-8

5. Avadhanula V, Rodriguez CA, Ulett GC, Bakaletz LO, Adderson EE (2006) Nontypeable haemophilus influenzae adheres to intercellular adhesion molecule 1 (ICAM-1) on respiratory epithelial cells and upregulates ICAM-1 expression. Infect Immun 74:830-838. https://doi.org/10.1128//AI.74.2.830-83 8.2006

6. Bakema JE, Ganzevles SH, Fluitsma DM, Schilham MW, Beelen RH, Valerius T, Lohse $S$ et al (2011) Targeting FcalphaRI on polymorphonuclear cells induces tumor cell killing through autophagy. J Immunol 187:726-732. https://doi.org/10.4049/jimmunol.1002581

7. Barber DF, Faure M, Long EO (2004) LFA-1 contributes an early signal for NK cell cytotoxicity. J Immunol 173:3653-3659

8. Basani RB, D Andrea G, Mitra N, Vilaire G, Richberg M, Kowalska MA, Bennett JS, Poncz M (2001) RGD-containing peptides inhibit fibrinogen binding to platelet alpha (IIb)beta3 by inducing an allosteric change in the aminoterminal portion of alpha (Ilb). J Biol Chem 276:13975-13981. https://doi. org/10.1074/jbc.M011511200

9. Becknell B, Caligiuri MA (2008) Natural killer cells in innate immunity and cancer. J Immunother 31:685-692. https://doi.org/10.1097/CJ.0b013e318182 de23

10. Bennett JL, Lam C, Kalluri SR, Saikali P, Bautista K, Dupree C, Glogowska M, Case D, Antel JP, Owens GP et al (2009) Intrathecal pathogenic anti-aquaporin-4 antibodies in early neuromyelitis optica. Ann Neurol 66:617-629. https://doi. org/10.1002/ana.21802

11. Bergman I, Basse PH, Barmada MA, Griffin JA, Cheung NK (2000) Comparison of in vitro antibody-targeted cytotoxicity using mouse, rat and human effectors. Cancer Immunol Immunother 49:259-266

12. Brinkmann $V$, Reichard U, Goosmann $C$, Fauler B, Uhlemann $Y$, Weiss DS, Weinrauch Y, Zychlinsky A (2004) Neutrophil extracellular traps kill bacteria. Science 303:1532-1535. https://doi.org/10.1126/science.1092385

13. Buerkle MA, Pahernik SA, Sutter A, Jonczyk A, Messmer K, Dellian M (2002) Inhibition of the alpha-nu integrins with a cyclic RGD peptide impairs angiogenesis, growth and metastasis of solid tumours in vivo. Br J Cancer 86:788-795. https://doi.org/10.1038/sj.bjc.6600141

14. Chen JJ, Su XY, Xi XD, Lin LP, Ding J, Lu H (2008) Fibrinogen interaction of $\mathrm{CHO}$ cells expressing chimeric alphallb/alphavbeta3 integrin. Acta Pharmacol Sin 29:204-210. https://doi.org/10.1111/j.1745-7254.2008.00723.x

15. Choi PJ, Mitchison TJ (2013) Imaging burst kinetics and spatial coordination during serial killing by single natural killer cells. Proc Natl Acad Sci U S A 110:6488-6493. https://doi.org/10.1073/pnas.1221312110

16. Crane JM, Lam C, Rossi A, Gupta T, Bennett JL, Verkman AS (2011) Binding affinity and specificity of neuromyelitis optica autoantibodies to aquaporin-4 M1/M23 isoforms and orthogonal arrays. J Biol Chem 286:16516-16524. https://doi.org/10.1074/jbc.M111.227298

17. Dekkers BG, Bos IS, Gosens R, Halayko AJ, Zaagsma J, Meurs H (2010) The integrin-blocking peptide RGDS inhibits airway smooth muscle remodeling 
in a Guinea pig model of allergic asthma. Am J Respir Crit Care Med 181: 556-565. https://doi.org/10.1164/rccm.200907-1065OC

18. Doucey MA, Legler DF, Faroudi M, Boucheron N, Baumgaertner P, Naeher D, Cebecauer M, Hudrisier D, Ruegg C, Palmer E et al (2003) The beta1 and beta3 integrins promote T cell receptor-mediated cytotoxic T lymphocyte activation. J Biol Chem 278:26983-26991. https://doi.org/10.1074/jbc.M302 709200

19. Duan T, Smith AJ, Verkman AS (2018) Complement-dependent bystander injury to neurons in AQP4-IgG seropositive neuromyelitis optica. J Neuroinflammation 15:294. https://doi.org/10.1186/s12974-018-1333-z

20. Ferrante A, Thong YH (1980) Optimal conditions for simultaneous purification of mononuclear and polymorphonuclear leucocytes from human blood by the Hypaque-Ficoll method. J Immunol Methods 36:109-117

21. Frigeri A, Gropper MA, Umenishi F, Kawashima M, Brown D, Verkman AS (1995) Localization of MIWC and GLIP water channel homologs in neuromuscular, epithelial and glandular tissues. J Cell Sci 108(Pt 9):2993-3002

22. Gwalani LA, Orange JS (2018) Single degranulations in NK cells can mediate target cell killing. J Immunol 200:3231-3243. https://doi.org/10.4049/ jimmunol.1701500

23. Hinson SR, Mckeon A, Fryer JP, Apiwattanakul M, Lennon VA, Pittock SJ (2009) Prediction of neuromyelitis optica attack severity by quantitation of complement-mediated injury to aquaporin-4-expressing cells. Arch Neurol 66:1164-1167. https://doi.org/10.1001/archneurol.2009.188

24. Hinson SR, Mckeon A, Lennon VA (2010) Neurological autoimmunity targeting aquaporin-4. Neuroscience 168:1009-1018. https://doi.org/10.1 016/j.neuroscience.2009.08.032

25. Horner H, Frank C, Dechant C, Repp R, Glennie M, Herrmann M, Stockmeyer B (2007) Intimate cell conjugate formation and exchange of membrane lipids precede apoptosis induction in target cells during antibodydependent, granulocyte-mediated cytotoxicity. J Immunol 179:337-345

26. Hsu HT, Mace EM, Carisey AF, Viswanath DI, Christakou AE, Wiklund M, Onfelt B, Orange JS (2016) NK cells converge lytic granules to promote cytotoxicity and prevent bystander killing. J Cell Biol 215:875-889. https:// doi.org/10.1083/jcb.201604136

27. Jarius S, Wildemann B (2010) AQP4 antibodies in neuromyelitis optica: diagnostic and pathogenetic relevance. Nat Rev Neurol 6:383-392. https:// doi.org/10.1038/nrneurol.2010.72

28. Kapp TG, Rechenmacher F, Neubauer S, Maltsev OV, Cavalcanti-Adam EA, Zarka R, Reuning U, Notni J, Wester HJ, Mas-Moruno C et al (2017) A comprehensive evaluation of the activity and selectivity profile of ligands for RGD-binding integrins. Sci Rep 7:39805. https:/doi.org/10.1038/srep39805

29. Kataoka T, Shinohara N, Takayama H, Takaku K, Kondo S, Yonehara S, Nagai K (1996) Concanamycin a, a powerful tool for characterization and estimation of contribution of perforin- and Fas-based lytic pathways in cellmediated cytotoxicity. J Immunol 156:3678-3686

30. Lehmann C, Zeis M, Schmitz N, Uharek L (2000) Impaired binding of perforin on the surface of tumor cells is a cause of target cell resistance against cytotoxic effector cells. Blood 96:594-600

31. Lennon VA, Kryzer TJ, Pittock SJ, Verkman AS, Hinson SR (2005) lgG marker of optic-spinal multiple sclerosis binds to the aquaporin-4 water channel. J Exp Med 202:473-477. https://doi.org/10.1084/jem.20050304

32. Lennon VA, Wingerchuk DM, Kryzer TJ, Pittock SJ, Lucchinetti CF, Fujihara $K$, Nakashima I, Weinshenker BG (2004) A serum autoantibody marker of neuromyelitis optica: distinction from multiple sclerosis. Lancet 364:21062112. https://doi.org/10.1016/S0140-6736(04)17551-X

33. Lucchinetti CF, Mandler RN, McGavern D, Bruck W, Gleich G, Ransohoff RM, Trebst C, Weinshenker B, Wingerchuk D, Parisi JE et al (2002) A role for humoral mechanisms in the pathogenesis of Devic's neuromyelitis optica. Brain 125:1450-1461

34. Ludwig RJ, Vanhoorelbeke K, Leypoldt F, Kaya Z, Bieber K, McLachlan SM, Komorowski L, Luo J, Cabral-Marques O, Hammers CM et al (2017) Mechanisms of autoantibody-induced pathology. Front Immunol 8:603. https://doi.org/10.3389/fimmu.2017.00603

35. Ma T, Yang B, Gillespie A, Carlson EJ, Epstein CJ, Verkman AS (1997) Generation and phenotype of a transgenic knockout mouse lacking the mercurial-insensitive water channel aquaporin-4. J Clin Invest 100:957-962. https://doi.org/10.1172/JCI231

36. Matlung $H L$, Babes $L$, Zhao XW, van Houdt M, Treffers LW, van Rees DJ, Franke K, Schornagel K, Verkuijlen P, Janssen H et al (2018) Neutrophils kill antibody-opsonized cancer cells by trogoptosis. Cell Rep 23:3946-3959 e3946. https://doi.org/10.1016/j.celrep.2018.05.082
37. Misu T, Fujihara K, Kakita A, Konno H, Nakamura M, Watanabe S, Takahashi T, Nakashima I, Takahashi H, Itoyama Y (2007) Loss of aquaporin 4 in lesions of neuromyelitis optica: distinction from multiple sclerosis. Brain 130:12241234. https://doi.org/10.1093/brain/awm047

38. Misu T, Hoftberger R, Fujihara K, Wimmer I, Takai Y, Nishiyama S, Nakashima I, Konno H, Bradl M, Garzuly F et al (2013) Presence of six different lesion. types suggests diverse mechanisms of tissue injury in neuromyelitis optica. Acta Neuropathol 125:815-827. https://doi.org/10.1007/s00401-013-1116-7

39. Nielsen S, Nagelhus EA, Amiry-Moghaddam M, Bourque C, Agre P, Ottersen OP (1997) Specialized membrane domains for water transport in glial cells: high-resolution immunogold cytochemistry of aquaporin-4 in rat brain. J Neurosci 17:171-180

40. Oh H, Siano B, Diamond S (2008) Neutrophil isolation protocol. J Vis Exp. https://doi.org/10.3791/745

41. Papadopoulos MC, Verkman AS (2012) Aquaporin 4 and neuromyelitis optica. Lancet Neurol 11:535-544. https://doi.org/10.1016/S1474-4422(12 )70133-3

42. Papadopoulos MC, Verkman AS (2013) Aquaporin water channels in the nervous system. Nat Rev Neurosci 14:265-277. https://doi.org/10.1038/ nrn3468

43. Peluffo H, Gonzalez P, Aris A, Acarin L, Saura J, Villaverde A, Castellano B, Gonzalez B (2007) RGD domains neuroprotect the immature brain by a glial-dependent mechanism. Ann Neurol 62:251-261. https://doi.org/10.1 002/ana.21170

44. Phuan PW, Ratelade J, Rossi A, Tradtrantip L, Verkman AS (2012) Complement-dependent cytotoxicity in neuromyelitis optica requires aquaporin-4 protein assembly in orthogonal arrays. J Biol Chem 287:1382913839. https://doi.org/10.1074/jbc.M112.344325

45. Ratelade J, Asavapanumas N, Ritchie AM, Wemlinger S, Bennett JL, Verkman AS (2013) Involvement of antibody-dependent cell-mediated cytotoxicity in inflammatory demyelination in a mouse model of neuromyelitis optica. Acta Neuropathol 126:699-709. https://doi.org/10.1007/s00401-013-1172-z

46. Ratelade J, Verkman AS (2014) Inhibitor(s) of the classical complement pathway in mouse serum limit the utility of mice as experimental models of neuromyelitis optica. Mol Immunol 62:104-113. https://doi.org/10.1016/j. molimm.2014.06.003

47. Ratelade J, Zhang H, Saadoun S, Bennett JL, Papadopoulos MC, Verkman AS (2012) Neuromyelitis optica lgG and natural killer cells produce NMO lesions in mice without myelin loss. Acta Neuropathol 123:861-872. https://doi. org/10.1007/s00401-012-0986-4

48. Ritter AT, Mellman I (2016) Natural killer cell granules converge to avoid collateral damage. J Cell Biol 215:765-767. https://doi.org/10.1083/jcb.2 01612003

49. Roemer SF, Parisi JE, Lennon VA, Benarroch EE, Lassmann H, Bruck W, Mandler RN, Weinshenker BG, Pittock SJ, Wingerchuk DM et al (2007) Pattern-specific loss of aquaporin-4 immunoreactivity distinguishes neuromyelitis optica from multiple sclerosis. Brain 130:1194-1205. https:// doi.org/10.1093/brain/awl371

50. Russo MA, Paolillo M, Sanchez-Hernandez Y, Curti D, Ciusani E, Serra M, Colombo L, Schinelli S (2013) A small-molecule RGD-integrin antagonist inhibits cell adhesion, cell migration and induces anoikis in glioblastoma cells. Int J Oncol 42:83-92. https://doi.org/10.3892/ijo.2012.1708

51. Saadoun S, Bridges LR, Verkman AS, Papadopoulos MC (2012) Paucity of natural killer and cytotoxic T cells in human neuromyelitis optica lesions. Neuroreport 23:1044-1047. https://doi.org/10.1097/WNR.0b013e32835ab480

52. Saadoun $S$, Waters $P$, Bell BA, Vincent A, Verkman AS, Papadopoulos MC (2010) Intra-cerebral injection of neuromyelitis optica immunoglobulin G and human complement produces neuromyelitis optica lesions in mice. Brain 133:349-361. https://doi.org/10.1093/brain/awp309

53. Saadoun $S$, Waters $P$, MacDonald C, Bell BA, Vincent A, Verkman AS, Papadopoulos MC (2012) Neutrophil protease inhibition reduces neuromyelitis optica-immunoglobulin G-induced damage in mouse brain. Ann Neurol 71:323-333. https://doi.org/10.1002/ana.22686

54. Sabater L, Giralt A, Boronat A, Hankiewicz K, Blanco Y, Llufriu S, Alberch J, Graus F, Saiz A (2009) Cytotoxic effect of neuromyelitis optica antibody (NMO-IgG) to astrocytes: an in vitro study. J Neuroimmunol 215:31-35. https://doi.org/10.1016/j.jneuroim.2009.07.014

55. Saffarzadeh M, Juenemann C, Queisser MA, Lochnit G, Barreto G, Galuska SP, Lohmeyer J, Preissner KT (2012) Neutrophil extracellular traps directly induce epithelial and endothelial cell death: a predominant role of histones. PLoS One 7:e32366. https://doi.org/10.1371/journal.pone.0032366 
56. Sans E, Delachanal E, Duperray A (2001) Analysis of the roles of ICAM-1 in neutrophil transmigration using a reconstituted mammalian cell expression model: implication of ICAM-1 cytoplasmic domain and rho-dependent signaling pathway. J Immunol 166:544-551

57. Smith AJ, Jin BJ, Ratelade J, Verkman AS (2014) Aggregation state determines the localization and function of M1- and M23-aquaporin-4 in astrocytes. J Cell Biol 204:559-573. https://doi.org/10.1083/jcb.201308118

58. Sobel RA, Mitchell ME, Fondren G (1990) Intercellular adhesion molecule-1 (ICAM-1) in cellular immune reactions in the human central nervous system. Am J Pathol 136:1309-1316

59. Topham NJ, Hewitt EW (2009) Natural killer cell cytotoxicity: how do they pull the trigger? Immunology 128:7-15. https://doi.org/10.1111/j.1365-256 7.2009.03123.x

60. Tradtrantip L, Yao X, Su T, Smith AJ, Verkman AS (2017) Bystander mechanism for complement-initiated early oligodendrocyte injury in neuromyelitis optica. Acta Neuropathol 134:35-44. https://doi.org/10.1007/ s00401-017-1734-6

61. Urlaub D, Hofer K, Muller ML, Watzl C (2017) LFA-1 activation in NK cells and their subsets: influence of receptors, maturation, and cytokine stimulation. J Immunol 198:1944-1951. https://doi.org/10.4049/jimmunol.1601004

62. Valgardsdottir R, Cattaneo I, Klein C, Introna M, Figliuzzi M, Golay J (2017) Human neutrophils mediate trogocytosis rather than phagocytosis of CLL B cells opsonized with anti-CD20 antibodies. Blood 129:2636-2644. https://doi. org/10.1182/blood-2016-08-735605

63. Vincent T, Saikali P, Cayrol R, Roth AD, Bar-Or A, Prat A, Antel JP (2008) Functional consequences of neuromyelitis optica-lgG astrocyte interactions on blood-brain barrier permeability and granulocyte recruitment. J Immunol 181:5730-5737

64. Voskoboinik I, Whisstock JC, Trapani JA (2015) Perforin and granzymes: function, dysfunction and human pathology. Nat Rev Immunol 15:388-400. https://doi.org/10.1038/nri3839

65. Yanai F, Ishii E, Kojima K, Hasegawa A, Azuma T, Hirose S, Suga N, Mitsudome A, Zaitsu M, Ishida Y et al (2003) Essential roles of perforin in antigen-specific cytotoxicity mediated by human CD4+ T lymphocytes: analysis using the combination of hereditary perforin-deficient effector cells and Fas-deficient target cells. J Immunol 170:2205-2213

66. Yusa S, Catina TL, Campbell KS (2002) SHP-1- and phosphotyrosineindependent inhibitory signaling by a killer cell Ig-like receptor cytoplasmic domain in human NK cells. J Immunol 168:5047-5057

67. Zhang H, Bennett JL, Verkman AS (2011) Ex vivo spinal cord slice model of neuromyelitis optica reveals novel immunopathogenic mechanisms. Ann Neurol 70:943-954. https://doi.org/10.1002/ana.22551

68. Zhang H, Verkman AS (2013) Eosinophil pathogenicity mechanisms and therapeutics in neuromyelitis optica. J Clin Invest 123:2306-2316. https://doi. org/10.1172/JCl67554

\section{Publisher's Note}

Springer Nature remains neutral with regard to jurisdictional claims in published maps and institutional affiliations.

Ready to submit your research? Choose BMC and benefit from:

- fast, convenient online submission

- thorough peer review by experienced researchers in your field

- rapid publication on acceptance

- support for research data, including large and complex data types

- gold Open Access which fosters wider collaboration and increased citations

- maximum visibility for your research: over $100 \mathrm{M}$ website views per year

At $\mathrm{BMC}$, research is always in progress.

Learn more biomedcentral.com/submissions 